Journal of Clinical Investigation

Journal of Clinical In
Vol. 42, No. 3, 1963

\title{
STUDIES OF THE RETICULOENDOTHELIAL SYSTEM (RES). II. CHANGES IN THE PHAGOCYTIC CAPACITY OF THE RES IN PATIENTS WITH CERTAIN INFECTIONS *
}

\author{
By HENRY N. WAGNER, JR., MASAHIRO IIO, † AND RICHARD B. HORNICK with \\ THE TECHNICAL ASSISTANCE OF URSULA SCHEFFEL AND \\ BARBARA JABBOUR \\ (From the Division of Nuclear Medicine, The Johns Hopkins Medical Institutions, and the \\ Department of Medicine, University of Maryland School of Medicine, \\ Baltimore, $M d$.)
}

(Submitted for publication June 22, 1962; accepted November 29, 1962)

In our previous communication (1), we have presented data indicating that the phagocytic capacity of the reticuloendothelial system (RES) can be determined by measuring the rate of disappearance of various doses of radioisotopically labeled aggregated albumin particles from the circulation. Since our results followed the mathematical model suggested first by Michaelis and Menten in their studies of enzyme-substrate systems (2), it was possible to postulate that the rate of removal of small amounts of particulate matter from the blood is determined chiefly by the frequency of collision of the particles with RE cells. This concept is also consistent with the known dependence of the clearance rate of trace quantities of particles on the blood flow to the principal RES-containing organs, chiefly the liver and spleen (3). As the number of particles increases, however, the collision frequency is no longer a factor in the reaction velocity, the latter being governed only by the rate of the reaction of the particles with the RE cells. This is evidenced by the fact that progressively larger doses do not increase the rate of removal of the particles to a significant degree.

The details of the method and the analytical procedure are discussed in the previous paper (1). The purpose of this communication is to describe the effects of certain infections, namely, pneumococcal pneumonia, typhoid fever, sandfly fever, and tularemia, on the phagocytic capacity of the reticuloendothelial system in man.

* Aided by grant no. H-6454, U. S. Public Health Service.

†U. S. Public Health Service trainee.
SLBJECTS

Description of patients. Twenty adult patients admitted to the Johns Hopkins Hospital with pneumococcal pneumonia were studied. All had characteristic clinical evidence of pneumonia, and Pneumococci were isolated from the blood, or sputum, or both, of each patient. Thirty-six determinations of the rate of clearance of $0.025,2.5$, and $5.0 \mathrm{mg}$ per $\mathrm{kg}$ of body weight of aggregated albumin were made at various times after the onset of illness. Follow-up studies were performed on 18 patients at intervals up to seven weeks after the onset of the illness.

Patients with typhoid fever, sandfly fever, and tularemia were volunteers in a program designed to evaluate the efficacy of vaccination as a means of preventing these diseases $(4,5)$. The cooperation of the volunteers and officials of the Maryland House of Correction, Jessup, Maryland, and the diligence of the personnel caring for these patients made possible the studies reported here.

Three male volunteers between the ages of 25 and 30 were infected by the oral ingestion of a viable culture of Salmonella typhi. All had clinical, bacteriological, and immunological evidence of typhoid fever. Measurements were made of the capacity of the RES to remove injected albumin aggregates from the circulation before, during, and after the illness. RES function was measured every other day for a total of four weeks. The results were compared with control values obtained in 25 normal subjects.

Three volunteers of ages 31 to 32 were injected intravenously with plasma containing the virus of sandfly fever and developed the clinical findings of this disease.

Four subjects (ages 22 to 23) were infected by inhalation of aerosols containing virulent Pasteurella tularensis. All developed the clinical syndrome of tularemia. Two additional patients (ages 24 and 25) developed typical ulceroglandular tularemia after intradermal injection of the causative organisms into the volar surface of the forearm.

\section{METHODS AND RESULTS}

1) Pneumococcal pneumonia. Figure 1 illustrates the double-reciprocal plot of Lineweaver and Burk (6), re- 


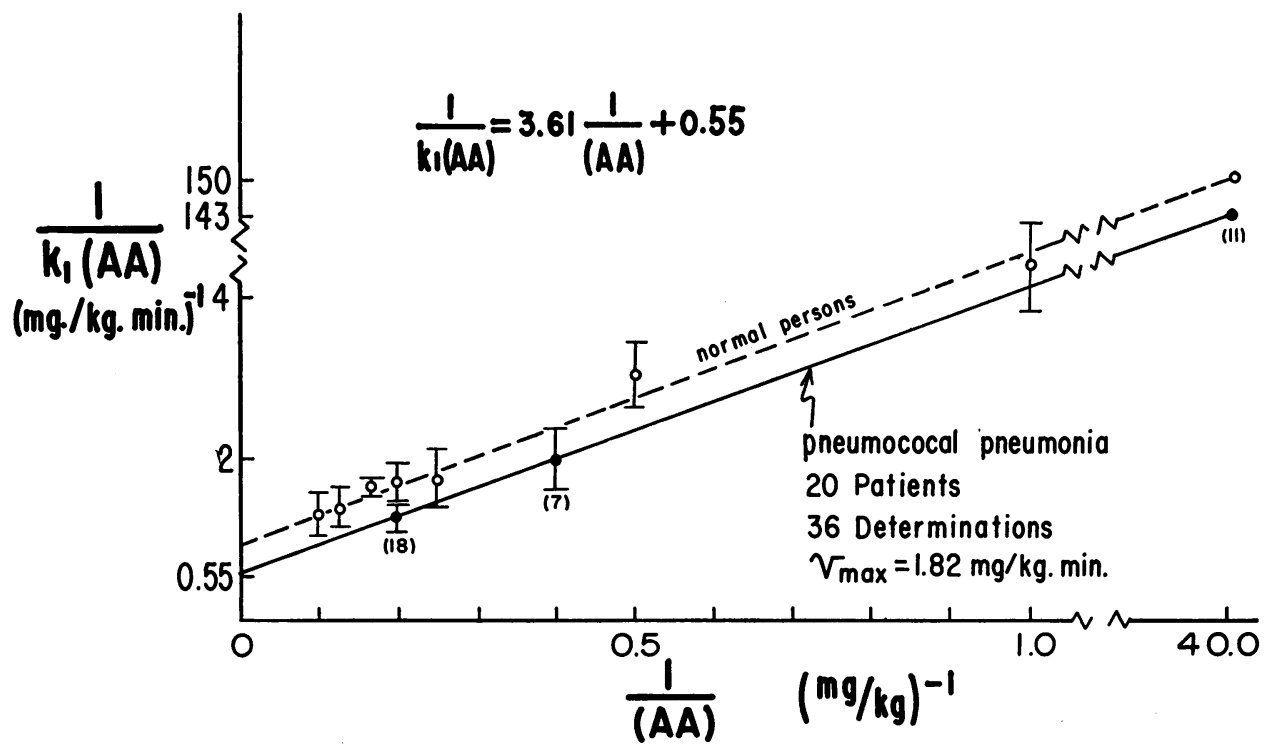

Fig. 1. Double-Reciprocal GRAPHS OF the RELATIONSHIP BETWEen the DOSE OF AGgREgated ALBUMIN (AA) AND THE RATE OF ITS CLEARANCE FROM THE BLOOD OF PATIENTS WITH PNEUMOCOCCAL PNEUMONIA AND OF NORMAL PERSONS.

lating $1 /(A A)$ to $1 / v$, where $(A A)=$ the administered dose of aggregated albumin and $v=$ the initial velocity of the reaction between the $A A$ particles and the RES. The data are presented in Table I.

As described in the previous communication (1), the initial velocity is obtained from the slope of the curve of disappearance of the $\mathrm{I}^{131}$-labeled aggregated albumin particles at zero time after injection. Experimentally, it was determined by graphing on semilog paper the plasma radioactivity at $5,7,10$, and 15 minutes after injection for the $0.025 \mathrm{mg}$ per $\mathrm{kg}$ dose and $5,10,15$, and 20 minutes after injection of larger doses. Because the initial disappearance rate was a close approximation of a straight line on semilog paper, the slope, $k$, was calculated as $0.693 / t_{1}$, where $t_{1}$ was the time in minutes required for the plasma radioactivity to reach a level onehalf that observed five minutes after injection, the fiveminute interval being allowed for physical mixing.

From the double reciprocal plot, the intercept, $1 / v_{\max }$, could be obtained, where $v_{\max }$ equaled the maximal rate

TABLE I

Blood clearance of aggregated albumin in man (pneumonia)

\begin{tabular}{lrcccc}
\hline \hline $\begin{array}{c}\text { Amount of } \\
\text { colloidal } \\
\text { albumin } \\
(A A)\end{array}$ & Studies & $\begin{array}{c}\text { Half- } \\
\text { time of } \\
\text { blood } \\
\text { clear- } \\
\text { ance }\end{array}$ & $\begin{array}{c}\text { Standard } \\
\text { deviation }\end{array}$ & $\begin{array}{c}\text { Fractional } \\
\text { clearance } \\
k_{1}\end{array}$ & $\begin{array}{c}\text { Clearance } \\
\text { rate } \\
k_{1}(A A)\end{array}$ \\
\hline$m g / k g$ & $n o$. & min & $\%$ & $m^{-1}$ & $\begin{array}{c}\text { mg/kg/ } \\
\text { min }\end{array}$ \\
0.025 & 11 & 2.5 & 25.3 & 0.280 & 0.007 \\
2.5 & 7 & 3.5 & 19.4 & 0.200 & 0.501 \\
5.0 & 18 & 4.4 & 12.2 & 0.159 & 0.795 \\
\hline
\end{tabular}

of removal of the $A A$ particles, i.e., the phagocytic capacity of the RES. The intercept was lower in patients with pneumococcal pneumonia than in normal persons. Thus, $v_{\max }$ in the pneumonia group equaled $1.82 \mathrm{mg}$ per minute per $\mathrm{kg}$ of body weight, compared to $1.07 \mathrm{mg}$ per $\mathrm{kg}$ per minute in normal persons. This represented an increase in the phagocytic capacity of the RES of $72 \%$.

In order to learn the time course of the change in phagocytic function associated with certain infections, we made multiple determinations of the rate of clearance of the $5 \mathrm{mg}$ per $\mathrm{kg}$ dose. This dose was selected because it was large enough to have its rate of clearance from the blood be primarily a function of the phagocytic function of the RES, rather than the rate of perfusion of the RES. The rate of removal of the $5 \mathrm{mg}$ per $\mathrm{kg}$ dose in normal persons was $55 \%$ that of the maximal velocity, $v_{\max }$.

Whenever changes were observed in the rate of clearance of the $5 \mathrm{mg}$ per $\mathrm{kg}$ dose, the clearance of the 0.025 $\mathrm{mg}$ per $\mathrm{kg}$ dose was measured on the following day to permit calculation of $v_{\max }$ according to the equation

$$
v_{\max }=\frac{39.8}{12.0 t_{1}^{\prime}-11.5 t_{1{ }_{1}^{\prime \prime}}^{\prime}},
$$

derived from the solution of the simultaneous equations describing the rate of clearance of the two different doses of colloidal particles; $t^{\prime}$ i equals the halftime of clearance of the $5 \mathrm{mg}$ per $\mathrm{kg}$ dose, and $t^{\prime \prime}{ }_{1}$ equals that of the 0.025 $\mathrm{mg}$ per $\mathrm{kg}$ dose.

Figure 2 illustrates sequential changes in the blood clearance half-time $\left(t_{1}\right)$ of a dose of $5 \mathrm{mg}$ per $\mathrm{kg}$ of aggregated albumin during illness and convalescence of the patients with pneumonia. It can be seen that the accelerated phagocytic activity began within three days of 
TABLE II

Half-time of clearance of aggregated albumin in three patients with typhoid fever *

\begin{tabular}{|c|c|c|c|c|c|c|c|c|c|c|c|c|c|c|}
\hline \multirow[b]{2}{*}{ Patient } & \multirow[b]{2}{*}{ Age } & \multirow[b]{2}{*}{ Sex } & \multirow{2}{*}{$\begin{array}{c}\text { Body } \\
\text { weight }\end{array}$} & \multicolumn{11}{|c|}{ Days after infection } \\
\hline & & & & -4 & 0 & 3 & 5 & 7 & 10 & 12 & 14 & 17 & 21 & 26 \\
\hline A.C. & 26 & M & $\begin{array}{c}\mathrm{kg} \\
76.5\end{array}$ & 5.5 & $\begin{array}{c}5.4 \\
(2.3)\end{array}$ & 5.8 & 5.0 & 5.2 & $\begin{array}{l}\min \\
4.3\end{array}$ & $\begin{array}{c}4.8 \\
(2.5)\end{array}$ & 5.2 & 5.2 & 6.0 & 5.4 \\
\hline P.W. & 25 & M & 58.5 & 5.9 & $\begin{array}{c}6.0 \\
(1.8)\end{array}$ & 5.2 & 6.3 & 5.8 & 5.5 & $\begin{array}{c}4.8 \\
(2.2)\end{array}$ & 4.7 & 5.1 & 6.2 & 6.6 \\
\hline T.D. & 30 & M & 75.0 & 6.0 & $\begin{array}{l}6.8 \\
(2.9)\end{array}$ & 5.9 & 5.5 & 5.7 & 4.8 & $\begin{array}{l}4.3 \\
(2.0)\end{array}$ & 6.1 & 6.4 & 5.9 & 5.7 \\
\hline
\end{tabular}

* Values represent the half-time of clearance of $5 \mathrm{mg}$ per $\mathrm{kg}$ and $0.025 \mathrm{mg}$ per $\mathrm{kg}$ (in parentheses) of aggregated albumin.

onset and that clearance rates returned to normal two weeks after the onset of symptoms.

2) Typhoid fever. Figure 3 and Table II present the data obtained in studies of the three patients with typhoid fever. The lower line indicates the onset of fever in the patients, as well as subsequent chloramphenicol therapy. All three patients developed fever, anorexia, and abdominal pain, accompanied by bacteremia and subsequent immunological response. Chloramphenicol therapy was followed by prompt defervescence and relief of symptoms.

The figure indicates the rate of clearance of a dose of aggregrated albumin of $5 \mathrm{mg}$ per $\mathrm{kg}$ at various times shown on the horizontal axis. Initially the values were within the normal range. An increase in the rate of clearance of aggregated albumin was noted on day 10 after infection in two of the patients and on day 12 in the third patient. Accelerated clearance began in each case only after fever had subsided. As indicated in Table II, the clearance of the small dose $(0.025 \mathrm{mg}$ per $\mathrm{kg})$ was essentially unchanged throughout the study, despite the increase in clearance of the $5.0 \mathrm{mg}$ per $\mathrm{kg}$ dose. The value, $v_{\max }$, was $58 \%$ higher during the period of increased clearance of the $5 \mathrm{mg}$ per $\mathrm{kg}$ dose of aggregated albumin than during the control period. This indicated a $58 \%$ increase in phagocytic function.

The duration of increased phagocytic activity was less in the patients with typhoid fever than in the patients with pneumococcal pneumonia, lasting only two to four days. At the time of the accelerated clearance, lymph nodes were palpable, but the spleen was not enlarged in any of the three subjects. One patient had a relapse after therapy and developed fever and symptoms on day 33 after infection. However, the accelerated clearance of the particulate matter did not recur during or after the relapse. No effect of chloramphenicol administration on the clearance rate was observed.

3) Sandfly fever. Figure 4 and Table III present the results of the study of three subjects with sandfly fever. Initially the clearance rate of a dose of $5 \mathrm{mg}$ per $\mathrm{kg}$ of aggregated albumin was within the normal range. In all three subjects, however, there was a decrease in the rate of clearance of the albumin particles shortly after the onset of the infection, highly suggestive of decreased phagocytic activity. Unfortunately, however, measurement of the clearance rate of the $0.025 \mathrm{mg}$ per $\mathrm{kg}$ dose was not made and therefore the change in $v_{\max }$ could not be determined. It is possible, but unlikely, that the decreased rate of clearance of the $5 \mathrm{mg}$ per $\mathrm{kg}$ dose was caused by decreased perfusion of the RES, rather than impaired function of $\mathrm{RE}$ cells. The impaired clearance of the aggregated albumin lasted for at least eight days before returning to normal.

4) Tularemia. The two subjects who developed ulceroglandular tularemia had no significant change in the rate of clearance of aggregated albumin from the blood (Table IV). In contrast, the patients with pneumonic tularemia were found to have an accelerated rate of clearance of the particles on days 6 and 8 after infection (Figure 5 ; Table V). Thereafter the clearance rate re-

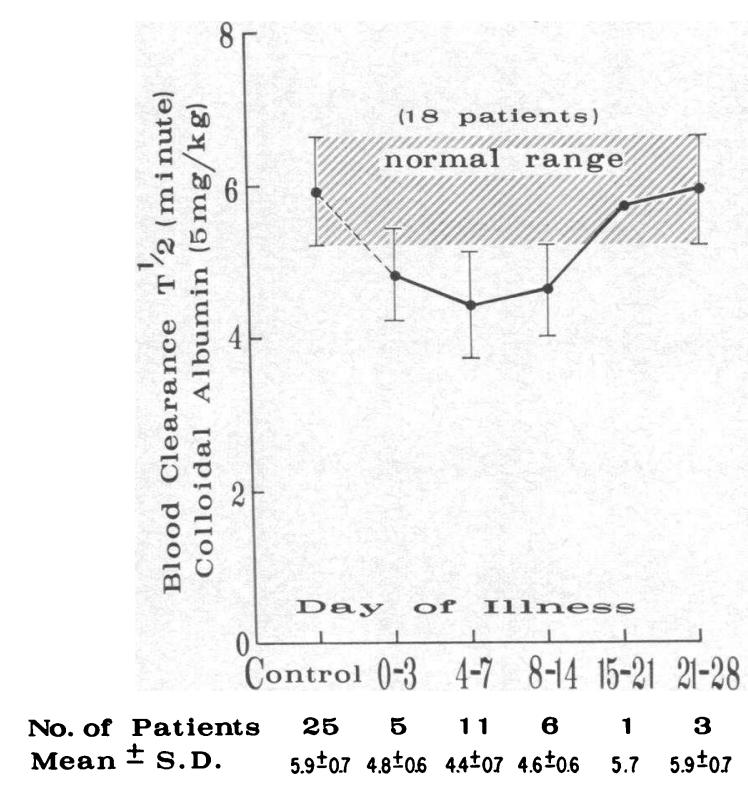

Fig. 2. Half-times of Clearance of aggregated alBUMIN ON VARIOUS DAYS OF ILLNESS IN PATIENTS WITH PNEUMOCOCCAL PNEUMONIA. 


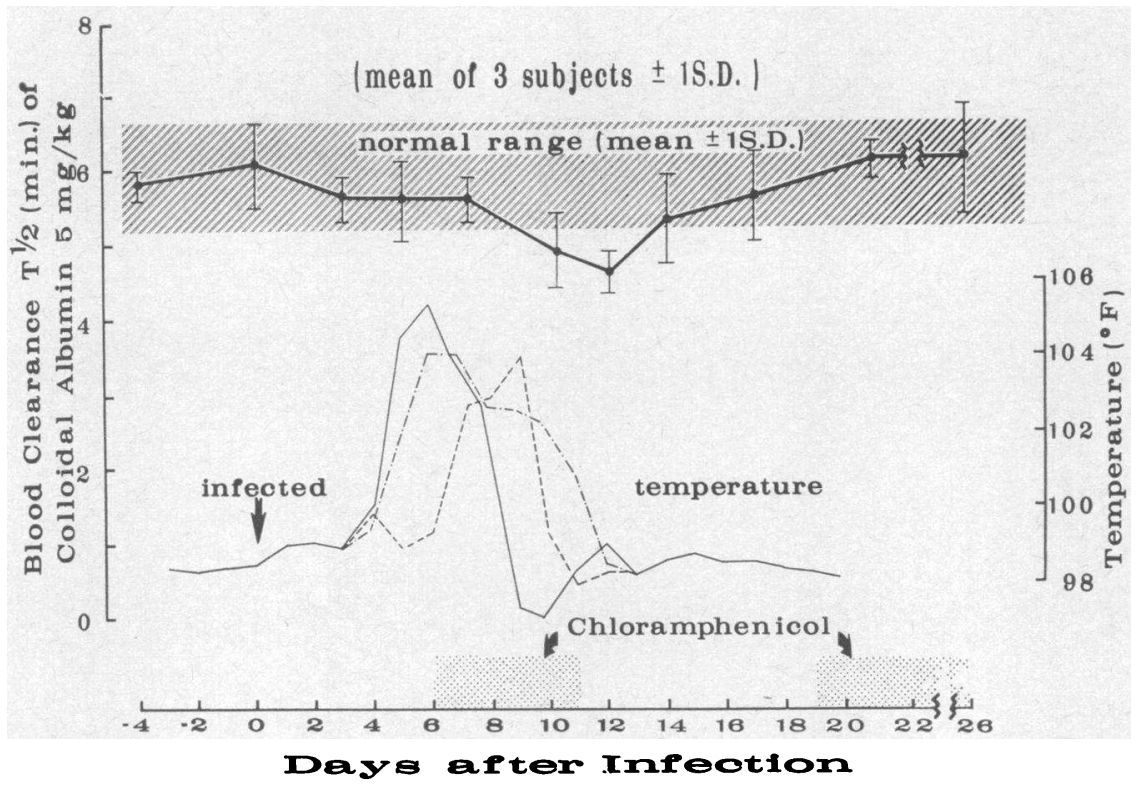

Fig. 3. InCREASEd Clearance RAte of AgGregated Albumin (DeCreased half-time) DURING THE COURSE OF EXPERIMENTAL TYPHOID.

turned to normal or even slower than normal values. As was observed in patients with typhoid fever, the increase in the rate of clearance of the $5 \mathrm{mg}$ per $\mathrm{kg}$ dose occurred after defervesence and clinical improvement.

\section{DISCUSSION}

These studies have demonstrated that in several bacterial infections in man, pneumococcal pneu- monia, typhoid fever, and probably pneumonic tularemia, one of the body's responses was an increase in its capacity to remove particulate matter in the form of aggregated human serum albumin from the circulation. The enhanced phagocytic ability could be disassociated from the concentration of circulating polymorphonuclear leukocytes in the blood, since increased phagocytic ca-

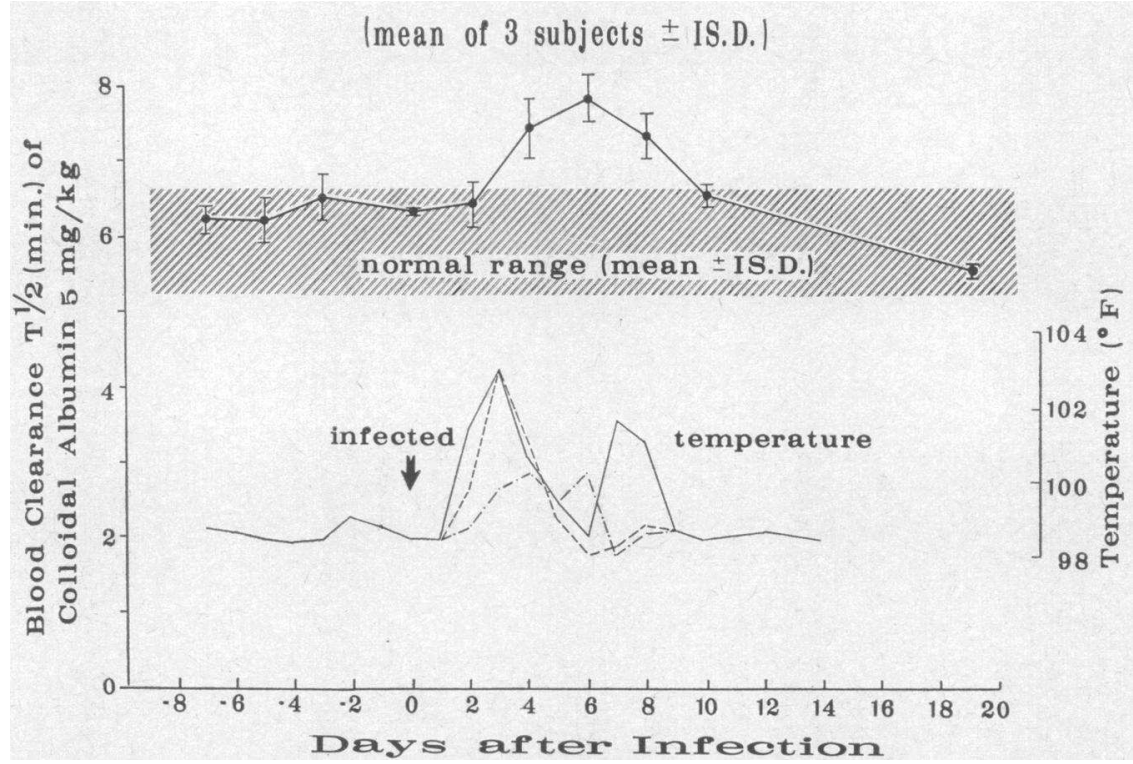

Fig. 4. DeCreased Clearance rate of AgGregated albumin (INCReased half-time) DURING THE COURSE OF EXPERIMENTAL SANDFLY FEVER. 
TABLE III

Half-time of clearance of aggregated albumin in three patients with sandfly fever *

\begin{tabular}{|c|c|c|c|c|c|c|c|c|c|c|c|c|c|}
\hline \multirow[b]{2}{*}{ Patient } & \multirow[b]{2}{*}{ Age } & \multirow[b]{2}{*}{$\operatorname{sex}$} & \multirow{2}{*}{$\begin{array}{c}\text { Body } \\
\text { weight }\end{array}$} & \multicolumn{10}{|c|}{ Days after infection } \\
\hline & & & & -7 & -5 & -3 & 0 & 2 & 4 & 6 & 8 & 10 & 19 \\
\hline & & & $k g$ & \multicolumn{10}{|c|}{$\min$} \\
\hline G.M. & 32 & M & 71.8 & 7.0 & 7.4 & $\begin{array}{c}7.7 \\
(3.1)\end{array}$ & 6.3 & 7.8 & 9.2 & 9.2 & 8.7 & 7.0 & 6.7 \\
\hline H.C. & 31 & $\mathrm{M}$ & 69.0 & 6.0 & 5.5 & $\begin{array}{c}5.8 \\
(2.8)\end{array}$ & 6.5 & 5.8 & 6.3 & 6.8 & 6.2 & 6.2 & 4.4 \\
\hline M.H. & 31 & $\mathrm{M}$ & 53.6 & 5.7 & 5.8 & $\begin{array}{c}6.1 \\
(2.7)\end{array}$ & 6.2 & 5.5 & 6.8 & 7.4 & 6.9 & 6.2 & 5.5 \\
\hline
\end{tabular}

* Values represent the half-time of clearance of $5 \mathrm{mg}$ per $\mathrm{kg}$ and $0.025 \mathrm{mg}$ per $\mathrm{kg}$ (in parentheses) of aggregated albumin.

pacity was observed during the leukopenic phase of typhoid fever.

In the viral infection, sandfly fever, we found highly suggestive evidence that an increased capacity for nonspecific phagocytosis was not necessary for recovery from the infection. In fact, there was evidence of an inhibitory effect of this viral infection on the ability of the body to remove particulate matter. In typhoid fever as well, an increased phagocytic ability occurred after the patients had shown signs of clinical response to chloramphenicol therapy, and at least two days after cessation of bacteremia. Only in pneumococcal pneumonia was there evidence of prolonged hyperactivity of phagocytosis of nonspecific material, the two-week period of hyperactivity corresponding to the time required for radiographic clearing of lobar consolidation.

The present data are consistent with the hypothesis that, in addition to its function in engulfing microorganisms, the RES functions as a nonspecific "scavenger," removing debris left behind as a result of infection or other damage to the body. To extend the hypothesis that phagocytosis may be important as a general scavenger, and not solely concerned with the natural resistance to infectious disease, we are now studying the effect of hemolysis, hematomata, burns, and other trauma as-

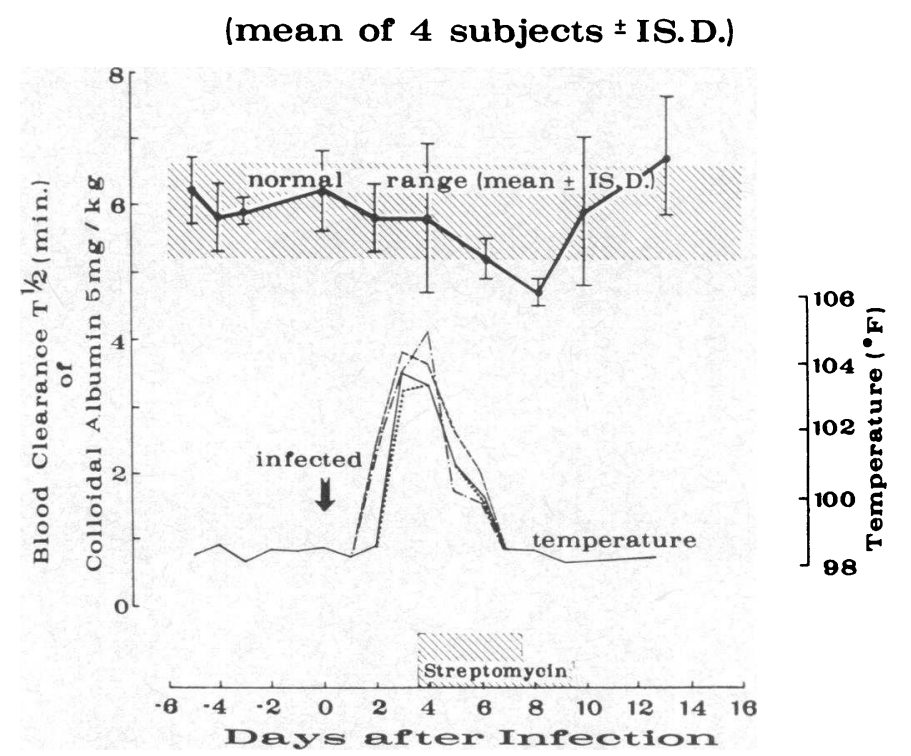

Fig. 5. InCREASEd Clearance Rate of AGgregated Albumin (DECREASEd half-time) DURING THE COURSE OF EXPERIMENTAL PNEUMONIC TULAREMIA. 
TABLE IV

Half-time of clearance of aggregated albumin in two patients with ulceroglandular tularemia*

\begin{tabular}{|c|c|c|c|c|c|c|c|c|c|c|c|}
\hline \multirow{2}{*}{$\begin{array}{c}\mathrm{Pa}- \\
\text { tient }\end{array}$} & \multirow[b]{2}{*}{ Age } & \multirow{2}{*}{\multicolumn{2}{|c|}{$\begin{array}{c}\text { Body } \\
\text { Sex weight }\end{array}$}} & \multicolumn{8}{|c|}{ Days after infection } \\
\hline & & & & -1 & 0 & 1 & 3 & 4 & 6 & 8 & 12 \\
\hline & & & kg & & & & $m i$ & & & & \\
\hline R.S. & 25 & $\mathbf{M}$ & 74.5 & 6.5 & $\begin{array}{c}5.1 \\
(3.2)\end{array}$ & 6.0 & 6.0 & $\begin{array}{c}5.5 \\
(2.9)\end{array}$ & 6.0 & 6.3 & 5.5 \\
\hline H.C. & 24 & $\mathbf{M}$ & 74.7 & 5.8 & $\begin{array}{c}5.5 \\
(1.8)\end{array}$ & 6.3 & 5.2 & $\begin{array}{c}5.2 \\
(3.2)\end{array}$ & 6.3 & 6.5 & 7.0 \\
\hline
\end{tabular}

* Values represent the half-time of clearance of $5 \mathrm{mg}$ per $\mathrm{kg}$ and 0.025 $\mathrm{mg}$ per $\mathrm{kg}$ (in parentheses) of aggregated albumin.

sociated with the production of tissue debris to see if there are associated increases in the functional capacity of the RES.

Previous studies in experimental animals are consistent with our present observations in human diseases. Biozzi, Halpern, Benacerraf, and Stiffel found an increased clearance of a dose of $160 \mathrm{mg}$ of carbon per $\mathrm{kg}$ of body weight in mice after injections of killed typhoid or tubercle bacilli (6). Of interest was the finding that no stimulation of phagocytosis was observed when killed Staphylococci were injected.

Prior to the use of aggregated albumin to study the functional capacity of the RES, bacterial endotoxins were used for this purpose. Since tolerance produced by repeated injections of bacterial endotoxins was attributed to an increased ability of the RES to remove endotoxin from the circulation $(7,8,9)$, the febrile response to an injection of endotoxin has been postulated to reflect the functional state of the RES. By this method, an "increased RES function" might be assumed in patients convalescing from naturally acquired typhoid fever (10) and experimental typhoid fever (11), and in a group of patients completing a course of malarial fever therapy (12). With tolerance or decreased febrile response to endotoxin as an indicator, no change in RES function was observed in patients recovering from bacillary dysentery, gonococcal arthritis, pneumococcal pneumonia or tularemia (10). The discrepancy between the results obtained by using endotoxin to evaluate the RES and our results with aggregated albumin is most apparent in the patients with pneumococcal pneumonia and tularemia. Morgan observed that there was no tolerance to endotoxin in patients recovering from pneumococcal pneumonia or tularemia. Bennett was also unable to demonstrate endotoxin tolerance during convalescence from pneumococcal skin infection in the rabbit (13). It must be emphasized that estimation of the phagocytic capacity of the RES will vary depending on whether one is measuring its capacity to clear nonspecific particulate matter from the circulation, determining the number of viable bacteria in the blood after injection of living bacterial organisms, or quantitating the degree of fever following an injection of endotoxin. In our opinion, however, measurement of the phagocytic capacity of the RES using aggregated albumin is the most direct means of studying the RES function concerned with removing nonspecific material from the circulation.

Whether the enhanced ability of the body to re-

TABLE V

Half-time of clearance of aggregated albumin in four patients with pneumonic tularemia *

\begin{tabular}{|c|c|c|c|c|c|c|c|c|c|c|c|c|c|}
\hline \multirow[b]{2}{*}{ Patient } & \multirow[b]{2}{*}{ Age } & \multirow[b]{2}{*}{ Sex } & \multirow{2}{*}{$\begin{array}{l}\text { Body } \\
\text { weight }\end{array}$} & \multicolumn{10}{|c|}{ Days after infection } \\
\hline & & & & -5 & -4 & -3 & $\mathbf{0}$ & 2 & 4 & 6 & 8 & 10 & 13 \\
\hline & & & $\mathrm{kg}$ & \multicolumn{10}{|c|}{$\min$} \\
\hline W.R. & 31 & M & 87.7 & 5.9 & $\begin{array}{c}5.3 \\
(2.0)\end{array}$ & 5.8 & 6.5 & 5.0 & 4.8 & $\begin{array}{c}5.0 \\
(2.0)\end{array}$ & 4.7 & 5.5 & 6.4 \\
\hline C.S. & 33 & M & 70.0 & 6.9 & $\begin{array}{c}6.2 \\
(2.5)\end{array}$ & 5.9 & 6.6 & 6.1 & 7.2 & $\begin{array}{c}5.0 \\
(1.8)\end{array}$ & 4.8 & 7.4 & 7.1 \\
\hline R.R. & 28 & M & 82.7 & 5.5 & (1.8) & 6.1 & 5.4 & 5.8 & 6.1 & $\begin{array}{c}5.5 \\
(1.9)\end{array}$ & 4.4 & 4.8 & 5.6 \\
\hline D.T. & 22 & M & 89.9 & 6.6 & $\begin{array}{c}6.0 \\
(2.8)\end{array}$ & 5.7 & 6.4 & 6.2 & 5.0 & $\begin{array}{c}5.4 \\
(2.3)\end{array}$ & 4.9 & 6.0 & 7.6 \\
\hline
\end{tabular}

*Values represent the half-time of clearance of $5 \mathrm{mg}$ per $\mathrm{kg}$ and $0.025 \mathrm{mg}$ per $\mathrm{kg}$ (in parentheses) of aggregated albumin. 
move particulate matter from the circulation is brought about by recruitment of newly formed reticuloendothelial cells or is due to an increased efficiency of the existing reticuloendothelial cells is not known. The finding that the rate of clearance of trace doses $(0.025 \mathrm{mg}$ per $\mathrm{kg}$ ) of aggregated albumin was not changed indicated that the increased clearance was not the result of increased perfusion of the RES, but rather of an increased extraction efficiency. One can correlate the increased clearance with the proliferation of lymphoid and histiocytic cells in the spleen, liver, bone marrow, and lungs observed in animals that were injected with living Staphylococci or paratyphoid vaccine (14). Whether the increased rate of removal results from the production of opsonins or humoral factors that enhance the efficiency of the RES remains conjectural (15).

\section{SUMMARY}

1) The phagocytic capacity of the reticuloendothelial system (RES) was measured in patients with pneumococcal pneumonia, typhoid fever, sandfly fever, and tularemia.

2) Pneumococcal pneumonia, typhoid fever, and probably pneumonic tularemia increased the maximal rate of removal of aggregated albumin particles from the circulation.

3) In sandfly fever, there was suggestive evidence of a decrease in the ability of the RES to remove this particulate matter from the circulation.

4) Enhanced phagocytosis was not related to the level of circulating polymorphonuclear leukocytes.

5) Enhanced phagocytic ability was observed after the patients had shown evidence of recovery from the infection.

6) In addition to its function in engulfing microorganisms, the RES seemed to function as a nonspecific "scavenger," increasing its capacity in response to debris left behind as a result of infection.

7) The use of aggregated albumin was safe both from an immunological and radiation standpoint, and provided an effective means of studying the body's ability to clear nonspecific particulate matter from the circulation.

\section{ADDENDUM}

Since preparation of our original manuscript, we have been able to confirm the increase in phagocytic capacity of the RES in human experimental typhoid fever. Four additional volunteers were infected with an oral dose of viable Salmonella typhi organisms. The phagocytic capacity increased from a control value of $0.87 \mathrm{mg}$ per $\mathrm{kg}$ per minute to a maximal value of $1.50 \mathrm{mg}$ per $\mathrm{kg}$ per minute. In contrast to the short period of increased phagocytic capacity in the original study, the second group manifested increased activity for a period of six days, presumably the result of a more prolonged clinical course. Furthermore, the $72 \%$ increase in $v_{\max }$ was higher than the original study.

We have also confirmed the lack of antigenicity of multiple doses of aggregated albumin administered to four subjects at frequent intervals over a period of three months.

We have also examined the changes in the phagocytic capacity of the reticuloendothelial system in a second viral infection, namely, experimental dengue fever in man. The maximal rate of removal of the aggregated albumin particles decreased to $39 \%$ and $45 \%$ of control values during the period of illness in each of two infected volunteers. Thus, both viral infections that we have studied to date, i.e., sandfly and dengue fevers, have been found to inhibit the body's ability to phagocytize aggregated albumin particles. This is in marked contrast to the enhanced phagocytic ability observed in bacterial infections.

\section{REFERENCES}

1. Iio, M., and H. N. Wagner, Jr. Studies of the reticuloendothelial system (RES). I. Measurement of the phagocytic capacity of the RES in man and dog. J. clin. Invest. 1963, 42, 417.

2. Michaelis, L., and M. L. Menten. Die Kinetik der Invertinwirkung. Biochem. Z. 1913, 49, 333.

3. Razzak, M. A., and H. N. Wagner, Jr. Measurement of hepatic blood flow by colloidal gold clearance. J. appl. Physiol. 1961, 16, 1133.

4. Hornick, R. B., T. E. Woodward, M. J. Snyder, L. J. Morse, and F. R. McCrumb. Studies of typhoid fever induced in volunteers. To be published.

5. Hornick, R. B., E. Gangarosa, J. T. Bulkeley, F. R. McCrumb, and T. E. Woodward. Studies in man on the immunoprophylaxsis of tularemia. To be published.

6. Biozzi, G., B. N. Halpern, B. Benacerraf, and C. Stiffel. Phagocytic activity of the reticuloendothelial system in experimental infections in Physiopathology of the Reticuloendothelial System. A Symposium. Oxford, Blackwell Scientific Publications, 1957, p. 204.

7. Beeson, P. B. Development of tolerance to typhoid bacterial pyrogen and its aboliton by reticulo-endothelial blockade. Proc. Soc. exp. Biol. (N. Y.) 1946, 61, 248. 
8. Beeson, P. B. Tolerance to bacterial pyrogens. II. Role of the reticuloendothelial system. J. exp. Med. 1947, 86, 39.

9. Thomas, L. The physiological disturbances produced by endotoxins. Ann. Rev. Physiol. 1954, 16, 467.

10. Morgan, H. R. Resistance to the action of the endotoxins of enteric bacilli in man. J. clin. Invest. 1948, 27, 705.

11. Greisman, S. E., T. E. Woodward, R. B. Hornick, M. J. Snyder, and F. A. Carozza. Typhoid fever: a study of pathogenesis and physiologic abnormalities. Trans. Amer. clin. climat. Ass. In press.

12. Heyman, A., and P. B. Beeson. Influence of various disease states upon the febrile response to in- travenous injection of typhoid bacterial pyrogen with particular reference to malaria and cirrhosis of the liver. J. Lab. clin. Med. 1949, 34, 1400.

13. Bennett, I. L. Observations of the fever caused by bacterial pyrogens. I. A study of the relationship between the fever caused by bacterial pyrogens and the fever accompanying acute infections. J. exp. Med. 1948, 88, 267.

14. Sullivan, F. L., E. F. Nackerrmann, and P. R. Cannon. The localizaton and fate of bacteria in the tissue. J. Immunol. 1934, 26, 49.

15. Jenkin, C. R., and D. Rowley. The role of opsonins in the clearance of living and inert particles by cells of the reticuloendothelial system. J. exp. Med. 1961, 114, 363. 